\title{
Mitigation of cadmium toxicity in Thai rice cultivar (PSL2) using biofertilizer containing indigenous cadmium-resistant microbial consortia
}

\author{
Preeyaporn Koedrith ( $\sim$ preeyaporn.koe@mahidol.edu ) \\ Mahidol University https://orcid.org/0000-0003-0160-6904 \\ Ladda Seang-On \\ Mahidol University \\ Weeradej Meeinkuirt \\ Mahidol University \\ Seriwat Saminpanya \\ Srinakharinwirot University
}

\section{Research Article}

Keywords: Bioremediation, Biofertilizer, Cd-resistant microbial consortia, Phytotoxicity, Indigenous soil microorganisms, Thai rice cultivar

Posted Date: September 21st, 2022

DOI: https://doi.org/10.21203/rs.3.rs-1320460/v2

License: (9) This work is licensed under a Creative Commons Attribution 4.0 International License. Read Full License 


\section{Abstract}

Biofertilizer as amendment has growing awareness, little attention has been paid to the bioremediation potential of indigenous heavy metal-resistant microbes, especially when isolated from long term polluted soil, as a bioinoculant in biofertilizer. They are type of versatile nutrient provider and soil conditioner that is cost competitive, highly efficient with nondisruptive detoxifying capability. Herein, we investigated the effect of biofertilizers containing indigenous cadmium (Cd)-resistant microbial consortia on rice growth and physiological response. The Thai rice cultivar PSL2 (Oryza sativa L.) was grown in Cd-enriched soils amended with $3 \%$ biofertilizer. The composition of the biofertilizers' bacterial community at different taxonomic levels was explored using 16S rRNA gene Illumina MiSeq sequencing. Upon Cd stress, the test biofertilizer had maximum mitigating effects as shown by suppressed photosynthetic pigment loss, modulated proline content and enzymatic antioxidants, thereby allowing increased plant dry biomass (up to $115 \%$ and $112 \%$ in shoots and roots, respectively) and reduced Cd bioaccumulation (up to $68 \%$ and $65 \%$ in shoots and roots, respectively), as compared to the non-amended control. These phenomena might be attributed to increased soil pH, EC, CEC and organic matter, as well as enriched beneficial detoxifiers, i.e., Bacteroidetes, Firmicutes, and Proteobacteria in the biofertilizers. The test biofertilizer was effective in ameliorating $\mathrm{Cd}$ phytotoxicity by improving soil biophysicochemical traits to limit $\mathrm{Cd}$ bioavailability, along with adjusting physiological traits such as antioxidative defense. This study first demonstrated that incorporating indigenous $\mathrm{Cd}$-resistant microbe derived-biofertilizer could restrict $\mathrm{Cd}$ contents and consequently enhance plant growth and tolerance in polluted soil.

\section{Introduction}

Heavy metal pollution of soils has been a concerning and persistent environmental problem worldwide. Canal irrigation water mixed together with untreated industrial and agricultural wastewater is considered a major source of soil pollution; thus, degrading agricultural land (Rafique et al. 2019; Shah et al. 2020). Releasing large quantities of untreated wastewater containing heavily toxic metals, i.e., $\mathrm{Cd}, \mathrm{As}, \mathrm{Ni}, \mathrm{Pb}$ and $\mathrm{Cr}$, and letting them transfer by irrigation to water bodies and soils, leads to toxicity and lower yields of unsafe crops with unsatisfactory quality (Din et al. 2020;Gill et al. 2016;Tanwir et al. 2015). Cadmium (Cd) contamination of soil from various potential sources including mining and smelting, sewage sludge in agriculture, and industrial releases constitutes a severe environmental issue because $\mathrm{Cd}$ is nonbiodegradable and a highly toxic element conferring deleterious impacts on the food chain and to human health (Khan 2005;Rizwan et al. 2017; Tchounwou et al. 2012). It exhibits extreme toxicity even at low concentration, owing to its high accumulation, mobility and persistency in living systems (Javed et al. 2019). Cellular $\mathrm{Cd}$ influx in plants is mediated through calcium transport protein channels or specific membrane transport proteins involved in ion transport across plasmalemma (Lux et al. 2011). In cereal crops, Cd has adverse effects on seed germination, growth, transpiration, anti-oxidative systems, photosynthetic rate, nitrogen assimilation and yield (Javed et al. 2019;Rizwan et al. 2017; Sarwar et al. 2015; Tanwir et al. 2015). 
Tak Province in northwestern Thailand, is located in close proximity to the Padaeng zinc (Zn) mining site, having areas exhibiting excessive levels of $\mathrm{Cd}$ in agricultural soils where health and environmental problems have been identified (Simmons et al. 2003). This has raised strong concerns because the International Water Management Institute discovered significant $\mathrm{Cd}$ contamination in rice grains and paddy soils in this province (Simmons et al. 2005). These elevated Cd levels (ranging from 3.4 to 284.0 $\mathrm{mg} \mathrm{kg}^{-1}$ in agricultural areas) are remarkably higher relative to the European Community limit of $3 \mathrm{mg}$ $\mathrm{kg}^{-1}$, posing high risk to the environment and human health (Swaddiwudhipong et al. 2012). The augmented deposition of $\mathrm{Cd}$ in water bodies and agricultural soils threatens the health status of plants, animals and humans.

Using industrial residues to remediate heavy metal contaminated wastewater has recently received attention as it not only facilitates the remediation efficiency of contaminants, but also promotes the recycling of wastes. For instance, innovative carbonaceous nano-chlorapatites (CNCIAPs) synthesized by the mixture of bamboo residues and chlorapatites under pyrolysis at 400 to $600^{\circ} \mathrm{C}$ were used to remove $\mathrm{Pb}$ (II) and tetracycline from wastewater. The higher the pyrolytic temperature is, the higher the removal efficacy becomes. Adsorption testing has revealed that the interaction of $\mathrm{Pb}$ (II) and tetracycline could facilitate removing these dual contaminants at low concentrations in wastewater using CNCIAPs (Deng et al. 2019). Furthermore, using sodium lignin sulfonate (SLS), a byproduct of the pulping and papermaking industry as a dispersant to synthesize a novel and ecofriendly SLS stabilized nano-chlorapatite (SNCIAP), could promote the removal efficiency of $\mathrm{Pb}$ (II) and Cd (II) from sediment (Deng et al. 2020). Regarding the remediation potential of SNCIAP in Cd-polluted sediment, the succession of microbial communities after remediation, especially phosphate-solubilizing bacterium Pseudomonas, was investigated. In addition, changes in microbial enzyme activity of catalase and urease were highly affected by the stability and bioavailability of $\mathrm{Cd}$. It not only shed light on a novel remediation tool for Cd-polluted sediment but also provided insights on the change of microenvironments related to the stability and bioavailability of $\mathrm{Cd}$ in sediment (Deng et al. 2020).

Many physicochemical methods have been widely used to reduce toxicity and recover polluted agricultural sites. Alternatively, one bioremediation method using bioadsorbents, i.e., microorganisms, to reduce $\mathrm{Cd}$ mobility in soils can be adopted to cope with metal pollution in soils. The adsorption/removal of environmental pollutants via soil microbial metabolic potential provides an economical and safe technique compared with other physicochemical methods. Bioremediation using indigenous heavy metalresistant microorganisms conferring heavy metal removal and plant growth promoting potential would prove a promising choice for agricultural sustainability in metal contaminated soil (Govindasamy et al. 2011).

Biofertilizers, are usually formed by the (semi-) solid state fermentation of agro-industrial wastes, and consist of both beneficial microbes and primary nutrients or plant growth regulating substances (Chen et al. 2011). Incorporating biofertilizers in soil would help produce antibiotics and stimulate biodegradation of soil organic matter (OM), increasing nutrient supplies, and enhancing plant tolerance to environmental stress. Microbial strains isolated from polluted environments exhibited resistance to higher levels of 
metals than those isolated from unpolluted areas (Rajkumar et al. 2010). Through metal-stress responsive mechanisms, soil microbes applied as biofertilizers effectively promoted the growth of plants implanted in heavy metal enriched soils by lowering metal-induced phytotoxicity (Madhaiyan et al. 2007;Wani \&Khan 2010). In addition, other mechanisms, i.e., plant growth promoting bacteria (PGPB) boost plant development. For instance, they protect colonizing plants by suppressing pathogens by producing antibiotics, hydrogen cyanide and phenazines etc.(Cazorla et al. 2007; Saravanakumar et al. 2007). PGPB also enhance plant growth via $\mathrm{N}_{2}$ fixation (Jha \&Kumar 2007), solubilizing insoluble phosphorus (Ahemad \&Khan 2012b), forming siderophores (Jahanian et al. 2012;Tian et al. 2009) and phytohormones (Ahemad \&Khan 2012a;Ahemad \&Khan 2012b;Tank \&Saraf 2010), reducing ethylene content (Rodrigues et al. 2008;Tank \&Saraf 2010), synthesizing antibiotics and antifungal metabolites and inducing systemic resistance (Glick 2012). Also, PGPB are able to increase the soil fertility and in turn, the plant yield by providing essential nutrients, growth regulating substances (Ahemad \&Khan 2012d) and lowering ethylene-based stress by inducing 1-aminocyclopropane-1-carboxylate deaminase and facilitating plant resistance to abiotic contaminants, e.g., metals and pesticides (Ahemad \&Khan 2012c;Glick 2012;Khan 2005). Exploiting the potential of PGPB to detoxify metals as well as versatile plant advantageous characteristics constitutes a potent, cost effective and ecofriendly metal bioremediating tool. Hence, biofertilizers have been recognized as clean and efficient soil conditioners or amendments to improve soil characteristics (Bhardwaj et al. 2014;Gajdos et al. 2012;Shen et al. 2013).

Nevertheless, the efficiency of biofertilizers derived from indigenous Cd-resistant microbial consortia isolated from Cd-contaminated soil in reducing Cd phytotoxicity has not been well documented.

Accordingly, soil with long term Cd contamination caused by the mining and smelting activities in Tak Province of Thailand was selected as our focus. The overall objective of this study was to evaluate the effect of biofertilizer treatments on alleviating $\mathrm{Cd}$ phytotoxicity by assessing plant growth performance, physiological response and Cd bioaccumulation within different parts of the Thai rice cultivar PSL2 (Oryza sativa L.) until the physiological maturity growth stage. The effects of test biofertilizers on soil properties and bioavailable $\mathrm{Cd}$ content were also examined at growth end stage.

\section{Materials And Methods}

\section{Collection and analysis of soil samples}

The long term polluted top soils ( $<20 \mathrm{~cm}$ in depth) used for greenhouse experiments were sampled from an agricultural area in Pha Dei Village, Mae Sot District, Tak Province, Thailand (N 16 40'35.9" E 98 $37^{\prime}$ $\left.37.4^{\prime \prime}\right)$ at an altitude of $197 \mathrm{~m}$. The soil at this site was tilled for either rice-corn or rice-bean crops in one cropping year. The selected physicochemical characteristics of the soil are shown in Table 4-1 \& 4-2. Soil samples were divided in two main portions: one for physicochemical characterizations and the other for enriched culture following biofertilizer preparation.

Soil material was homogenized, air-dried, crushed, and sieved (2-mm mesh size). The following physicochemical properties of the soil were determined: $\mathrm{pH}$ and electrical conductivity (EC) (1:5 
soil/water suspensions) using a pH meter and an EC meter respectively; OM content by wet oxidization and titration according to the modified Walkley-Black procedure(Nelson \&Sommers 1996); cation exchange capacity (CEC) using $1 \mathrm{~N}$ ammonium chloride $\mathrm{pH} 7.0$ after pretreatment to remove soluble salts (Oorts et al. 2007); total N by the Kjeldahl method; extractable P by Bray II method (Bray \&Kurtz 1945) and extractable K using an atomic absorption spectrophotometer (Perkin Elmer Analyst 200, USA) after ammonium acetate extraction at $\mathrm{pH} 7$.

\section{Preparation and analysis of Cd-resistant biofertilizer}

The biofertilizers used as amendments for remediation of $\mathrm{Cd}$ contaminated soils were prepared using repeated culture enrichment of the soil Cd-resistant bacteria as previously described (Seang-On et al. 2019) followed by semi-solid fermentation/biofertilization conditions. Topsoil ( $<20 \mathrm{~cm}$ in depth) was collected from a long- term Cd and Zn-contaminated agricultural area in Pha Dei Village, Mae Sot District, Tak Province (N 16 40' 35.9" E $98^{\circ} 37^{\prime} 37.4^{\prime \prime}$ ) at an altitude of $197 \mathrm{~m}$ for culture enrichment. To enrich Cd-resistant bacteria (BC), the first $5 \mathrm{~g}$ of each topsoil sample was added to $95 \mathrm{ml}$ of nutrient broth (NB, $0.5 \%$ peptone, $0.3 \%$ meat extract, $\mathrm{pH} 7.0)$ containing 50 or $100 \mathrm{ppm} \mathrm{Cd}$ chloride $\left(\mathrm{CdCl}_{2}\right)$. After two weeks of consecutive incubation at $30^{\circ} \mathrm{C}$, the bacteria were cultured on nutrient agar plates (NA, nutrient broth and $1.5 \%$ agar) supplemented with $\mathrm{CdCl}_{2}$ for $72 \mathrm{~h}$ at $30^{\circ} \mathrm{C}$. The colonies of Cd-resistant bacteria were quantified as colony forming units per $\mathrm{ml}\left(\mathrm{CFU} \mathrm{ml}{ }^{-1}\right)$. The test biofertilizer (BF) was prepared under aerobic conditions, using enriched $\mathrm{BC}$ with rice bran supplemented with micronutrients and mineral additives to stimulate fermentation. The organic fertilizer (OF) was produced by fermenting the rice bran supplemented with micronutrients and mineral additives as mentioned in an aerobic environment, in absence of $\mathrm{BC}$. The biofertilizers were stored at $4^{\circ} \mathrm{C}$ prior to use in greenhouse experiments. Hence, the treatments used in this study were listed in Table 1. The main components and bacterial compositions of each amendment are shown in Table 2.

For physicochemical analyses, properties of the biofertilizers as soil amendments or conditioners were determined: $\mathrm{pH}$ using a $\mathrm{pH}$ meter and $\mathrm{OM}$ content using wet oxidization and titration according to the modified Walkley-Black procedure (Nelson \&Sommers 1996). Total contents of metal elements including $\mathrm{Cd}, \mathrm{Zn}, \mathrm{Ca}, \mathrm{Mg}, \mathrm{S}, \mathrm{Fe}$ and $\mathrm{Mn}$ in biofertilizer samples were determined using microwave digestion and quantification using an atomic absorption spectrophotometer (Perkin Elmer AAnalyst 200).

Bacterial diversity and composition of the test biofertilizers compared with the enriched consortia were analyzed using 16S rRNA gene Illumina MiSeq sequencing as previously described (Seang-On et al. 2019). Total genomic DNA was extracted from $10 \mathrm{ml}$ of the enriched culture and the biofertilizers were tested (three biological replicates per treatment) using QIAamp ${ }^{\circledR}$ DNA Stool Mini Kit (Qiagen, Germany) according to the manufacturer instructions with some modifications. The 16S rDNA (V3-V4) bacterial primers containing the Illumina overhang adapter sequences (as underlined) $341 \mathrm{~F}\left(5^{\prime}\right.$ -

TCGTCGGCAGCGTCAGATGTGTATAAGAGACAGCCTACGGGNGGCWGCAG) and 805R (5'GTCTCGTGGGCTCGGAGATGTGTATAAGAGACAGGACTACHVGGGTATCTAATCC) were used for PCR amplification (Herlemann et al. 2011). The PCR mixtures $(25 \mu \mathrm{l}$ ) contained $12.5 \mu \mathrm{l}$ of $2 x \mathrm{KAPA}$ HiFi Hot 
Start Readymix (KAPA Biosystems, USA), $5 \mu$ of each primer $\left(1 \mu \mathrm{mol} \mathrm{I}^{-1}\right)$ and $2.5 \mu$ l of target DNA $\left(5 \mathrm{ng} \mu \mathrm{l}^{-}\right.$ $\left.{ }^{1}\right)$. The PCR cycling conditions consisted of an initial denaturation step at $94^{\circ} \mathrm{C}(3 \mathrm{~min})$, followed by 25 cycles of $98^{\circ} \mathrm{C}(20 \mathrm{sec}), 55^{\circ} \mathrm{C}(30 \mathrm{sec})$ and $72^{\circ} \mathrm{C}(30 \mathrm{sec})$ and a final elongation at $72^{\circ} \mathrm{C}(5 \mathrm{~min})$. The PCR products were cleaned-up on AMPure XP beads (Agencourt Bioscience, USA). The purified amplicons (550-bp fragments) were submitted to the Omics Sciences and Bioinformatics Center (Chulalongkorn University, Bangkok, Thailand) for paired-end sequencing on the Illumina MiSeq platform. Subsequently, the purified 16S RNA gene amplicons were then indexed using 2X KAPA hot-start ready mix and $5 \mu$ of each Nextera XT index primer in a $50 \mu \mathrm{l} \mathrm{PCR}$ reaction, followed by 8 to 10 cycles of PCR amplification. The PCR cycling was set as aforementioned. Next, the indexed 16S RNA gene amplicons were purified on AMPure XP beads (Agencourt Bioscience, USA), pooled and diluted to a final loading concentration of 4 pM. Cluster generation and 250-bp paired-end read sequencing were performed on an Illumina MiSeq using the MiSeq Reagent Kit. Amplicon sequence analysis was performed with QIIME version 1.9.0. (Caporaso et al. 2010). All sequence reads were sorted based on their unique barcodes, trimmed for sequence quality and clustered at $97 \%$ identity for operational taxonomic units (OTUs). The UCHIME algorithm was used to discard chimera sequences (Edgar et al. 2011).

The microbial diversity index in terms of diversity (Shannon index) and richness (Chao1 index) were subsequently computed using MOTHUR (Schloss et al. 2009). To investigate the microbial composition and diversity, the Shannon diversity index, an estimator of species richness and diversity using a natural logarithm, accounts for both abundance and evenness of the taxa present, while the Chao 1 richness estimator reflects diversity from abundance data and the number of rare taxa missed from undersampling.

\section{Greenhouse experimental design}

All the experiments involving plants adhered to the relevant ethical guidelines on plant usage. Table 1 present the treatments used in this study. A 2,000 g soil sample was crushed, sieved (2-mm mesh size), and placed in a plastic pot as previously described with some modifications (Wang et al. 2019). Biofertilizers were mixed in long-term Cd contaminated soil at a rate of $3 \%$. Hence, NPK basal fertilizer containing $0.25 \mathrm{~g}_{\text {urea kg }}^{-1}$ soil, $0.15 \mathrm{~g} \mathrm{KH}_{2} \mathrm{PO}_{4} \mathrm{~kg}^{-1}$ soil and $0.04 \mathrm{KCl} \mathrm{kg}^{-1}$ soil was initially dissolved in deionized water and thoroughly mixed with the soil in each pot. Subsequently, all pots were incubated with moisture at $75 \%$ of water holding capacity for five weeks to allow the nutrients in biofertilizers to be released in the soil, as well as promote the microbes in biofertilizers to work and to functionally act toward Cd stress. Thai rice seeds (PSL2) were sterilized with $5 \%$ hydrogen peroxide $\left(\mathrm{H}_{2} \mathrm{O}_{2}\right)$ for 5 min, rinsed with distilled water and placed in a Petri Dish containing two pieces of filter paper. After germination, eight rice seedlings were transplanted in each plastic pot. The pots were arranged in a randomized complete block design with six replicates for each treatment. During rice growth, each pot was irrigated every three days with distilled water to maintain soil moisture at ca. 60 to $70 \%$ of water holding capacity. Greenhouse conditions were as follows: temperature 26 to $40^{\circ} \mathrm{C}, 55$ to $70 \%$ relative humidity, 5,500 to 50,000 Ix light intensity, and a 12/12 h photoperiod. 
After 30 days of treatment, the roots and shoots were collected separately per biological replicate and stored at $4^{\circ} \mathrm{C}$ for measuring proline content, photosynthetic pigments and different enzymatic assays.

Four months after transplantation, the plant samples were washed with tap water, rinsed with deionized water several times until all excess soil was removed, and then the shoots and roots were harvested. Plant materials were oven-dried at $80^{\circ} \mathrm{C}$ for four days before determining weight. Soil material was collected from each pot and allowed to air-dry for five days. Soil and plant samples were subjected to chemical analyses.

\section{Measurement of total protein content}

The total protein content of rice leaves was quantified as previously described (Lowry \&Rosebrough 1951). Plant leaves $(0.5 \mathrm{~g})$ were ground and added with phosphate buffer. The mixture was centrifuged at $3,000 \mathrm{rpm}$ for $10 \mathrm{~min}$. The resulting supernatant $(0.1 \mathrm{~mL})$ was added with distilled water to make the volume up to $1 \mathrm{~mL}$. This solution was added with the equal volume of alkaline $\mathrm{CuSO}_{4}$ reagent and shaken for $10 \mathrm{~min}$. Finally, the Follin reagent was added and then incubated for $30 \mathrm{~min}$ at $28 \pm 2{ }^{\circ} \mathrm{C}$. Readings were measured at $650 \mathrm{~nm}$. Bovine serum albumin (BSA) was taken as a reference for the calculation of total protein contents.

\section{Estimation of photosynthetic pigments}

Photosynthetic pigments (chlorophyll (Chl) a, b, and carotenoids) of rice leaves were estimated as previously mentioned (Burnison 1980). Plant leaves $(0.5 \mathrm{~g})$ were added with $10 \mathrm{ml}$ of dimethyl sulfoxide (DMSO) and then heated at $65^{\circ} \mathrm{C}$ in water bath for $4 \mathrm{hrs}$. The supernatant was separated, and its absorbance was recorded at $663 \mathrm{~nm}, 645 \mathrm{~nm}$, for Chl a, Chl b, and $480 \mathrm{~nm}$ for carotenoids, respectively.

\section{Estimation of proline content}

Proline contents were determined by using previous protocol (Bates et al. 1973). Rice leaves $(0.5 \mathrm{~g})$ were ground in $80 \%$ ethanol and then heated at $80^{\circ} \mathrm{C}$ for $1 \mathrm{hr}$ in a water bath. After centrifugation, $0.5 \mathrm{ml}$

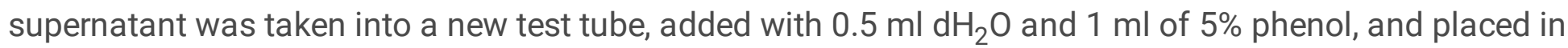
an incubator for $1 \mathrm{hr}$. After incubation, $2.5 \mathrm{ml}$ sulfuric acid was added and the readings were measured at $490 \mathrm{~nm}$.

\section{Determination of enzymatic antioxidant activities}

\section{Enzyme extracts}

For preparing enzyme extracts, $0.5 \mathrm{~g}$ leaves and roots were ground in $3 \mathrm{ml}$ phosphate buffer $(\mathrm{pH} 7.8)$ and subjected to homogenization on ice. The solution was made to $5 \mathrm{ml}$ and centrifuged at 13,000 rpm for 20 min at $4{ }^{\circ} \mathrm{C}$. The supernatant was covered with aluminum foil to avoid light exposure and stored at $4{ }^{\circ} \mathrm{C}$ for subsequent enzyme assays. 
APX (EC\# 1.11.1.11) activity was quantified by examining the rate of ascorbate oxidation at a wavelength of $290 \mathrm{~nm}$ as the previous method (Asada 1987). The reaction mixture consisted of $50 \mathrm{mM}$ phosphate buffer $\mathrm{pH} 7.0,0.1 \mathrm{mM} \mathrm{H}_{2} \mathrm{O}_{2}, 0.5 \mathrm{mM}$ ascorbic acid, and $100 \mu \mathrm{l}$ of enzyme crude extract.

\section{Superoxide dismutase (SOD) activity}

SOD (EC\# 1.15.1.1) activity was subjected to assess the inhibition in the photoreduction of nitro blue tetrazolium (NBT) as previous procedure (Beyer Jr \&Fridovich 1987). Reaction mixture was taken with 50 $\mathrm{mM}$ sodium phosphate buffer ( $\mathrm{pH}$ 7.6), $0.1 \mathrm{mM}$ EDTA, $50 \mathrm{mM}$ sodium carbonate, $12 \mathrm{mM}$ L-methionine, $50 \mu \mathrm{M}$ NBT, $10 \mu \mathrm{M}$ riboflavin, and $100 \mu$ of enzyme crude extract. For comparison, a set of reactions with all components except the crude extract was taken as control. To start the reactions, the reaction tubes were exposed to white light for $15 \mathrm{~min}$. Reactions were terminated by switching off the lights and readings were recorded at $560 \mathrm{~nm}$.

\section{Sampling and metal analyses of soil and plant tissue}

Total and extractable contents of metal elements in soil and plant samples were determined using microwave digestion and diethylenetriamine pentaacetate (DTPA) extraction, respectively. Total (strong acid-extractable) $\mathrm{Cd}$ and $\mathrm{Zn}$ in soil before and after planting was estimated by digesting approximately 1 $\mathrm{g}$ of air-dried soil with $4.5 \mathrm{ml}$ of $37 \%$ hydrochloric acid $(\mathrm{HCl}), 1.5 \mathrm{ml}$ of $65 \%$ nitric acid, and $1 \mathrm{ml}$ of $30 \%$ $\mathrm{H}_{2} \mathrm{O}_{2}$ in a microwave digestion system (Milestone ETHOS One, USA). A similar procedure was employed to digest plant materials, but without $\mathrm{HCl}$ addition. The amount of DTPA-extractable $\mathrm{Cd}$ and $\mathrm{Zn}$ in soil was determined using $0.005 \mathrm{M} \mathrm{DTPA}+0.01 \mathrm{M} \mathrm{CaCl}_{2}+0.1 \mathrm{M}$ triethanolamine, $\mathrm{pH} 7.30$ at a soil-to-solution ratio $(\mathrm{w} / \mathrm{v})$ of 1:2. The metal concentrations in both the digests and extracts were quantified using an atomic absorption spectrophotometer (Perkin Elmer AAnalyst 200).

\section{Statistical analyses}

Data were subjected to statistical analysis using two-way ANOVA (SPSS Software) to detect significant differences with $95 \%$ confidence level $(P$-value $\leq 0.05)$.

\section{Results}

\section{Relative abundance and composition structure of the test biofertilizers}

The relative abundance and composition of the test biofertilizers were assessed and compared with the enriched culture consortium using a 16S RNA gene amplicon sequencing approach. Table 2 summarizes bacterial composition in phyla of the biofertilizer. Table 3 shows the alteration in the diversity indices of the biofertilizers $\mathrm{BF}$, compared with the enriched bacterial consortia BC. Diversity indices of the biofertilizers BF were significantly higher than those of the enriched bacterial consortia BC samples, as shown by the increase in the Shannon diversity index and the Chao1 richness estimator. 
Fig. 1 shows the relative abundance of bacterial phyla in the biofertilizers and the enriched bacterial consortia. Proteobacteria, Bacteroidetes, Firmicutes and Gemmatimonadetes were the most dominant phyla. Rising Cd concentrations (20 to $100 \mathrm{ppm}$ ) added in the microbial culture could enrich a population of Cd-resistant bacterial phyla among other Cd-sensitive phyla (Seang-On et al. 2019). These enriched population of Cd-resistant bacteria was inoculated into the test biofertilizer used in this study. Using $16 \mathrm{~S}$ RNA gene amplicon sequencing, the three top main phyla including Firmicutes, Bacteroidetes and Proteobacteria were explored relative to the corresponding enriched culture (Table 3 and Fig. 1a). The relative abundance of Proteobacteria, Firmicutes, and Bacteroidetes increased across the biofertilization process, while those of Acidobacteria, Actinobacteria, Chloroflexi, Gemmatimonadetes, Planctomycetes and Verrucomicrobia decreased. Although a decrease in Acidobacteria, Gemmatimonadetes, and Planctomycetes was observed, they still somewhat remained throughout the biofertilization process. In the biofertilizer, predominant detoxifiers at a finer taxonomic level of Proteobacteria (including Comamonas sp., Pseudomonas sp., Stenotrophomonas sp., Acinetobactersp., and Delftia sp.), Firmicutes (including Enterococcus sp., Lactobacillus sp., and Lactococcus sp.), and Bacteroidetes (including Wautersiella sp., Myroides sp., Cloacibacterium sp., Paludibactersp.) were explored among other genera (Fig. 1b). The biofertilizer containing indigenous Cd-resistant bacterial consortium were successfully prepared and subjected to subsequent investigation.

\section{The effects of biofertilizer on soil physicochemical traits}

Table 2 shows physicochemical properties and bacterial composition in phyla of biofertilizer BF in comparison to the organic fertilizer OF. Under Cd stress, the application of biofertilizer BF showed maximum increase in soil $\mathrm{pH}, \mathrm{EC}, \mathrm{CEC}$, and $\mathrm{OM}$ as well as major mineral nutrition $\mathrm{N}, \mathrm{P}$, and $\mathrm{K}$ as compared with the non-amended control, with higher degree of increase than that of the other amendments (Table 4-1). This might be a result of the intrinsic $\mathrm{pH}$ of the biofertilizer (Table 2). The treatments by soil $\mathrm{pH}$ (Table 4), OM content (Table 2) and tissue Cd content (Table 6) were ranked in the order as BF > OF. All the amendments showed increase in soil $\mathrm{pH}$ and $\mathrm{OM}$ with different extent, these treatments could lower soil bioavailable $\mathrm{Cd}$ and rice tissue $\mathrm{Cd}$ contents as compared with the control (Table 4-1, 4-2 \& 6).

The level of DTPA-extractable metals including Cd, Zn, Fe, Mg, and Mn could be recommended as an potential indicator of the pool metal availability in soils and consequent bioaccumulation in plants (Catherine et al. 2006; Sun et al. 2007). All the amendments showed decrease in the levels of DTPAextractable $\mathrm{Cd}$ and $\mathrm{Zn}$ compared with the control (Table 4-2). Particularly, the application of biofertilizer exhibited the lowest level of DTPA-extractable $\mathrm{Cd}$, as shown by a $54 \%$ decrease in the Cd level compared with the non-amended control. This point might imply that in this phenomenon, there was association between the soil physical structure or chemical composition/fertility of the biofertilizers and the $\mathrm{Cd}$ availability/stability in soils.

\section{The effects of biofertilizer on rice growth under Cd stress}

Plant growth is a plausible determinant that reflects $\mathrm{Cd}$ phytotoxicity in polluted soils. The plants showed less biomass after exposure to $\mathrm{Cd}$ as compared to the non-stressed control. Cd mitigating potential of 
biofertilizer was observed for the rice plants grown in Cd-enriched soil over 4 months. Exposure of rice plants to Cd stress negatively affected the germination (as shown in our previous study, Seang-On et al. 2019) and their growth performance (Table 5).

All the amendments increased tendency of biomass and length of rice shoot and root under Cd stress, as compared to the non-amended stressed control CD (Table 5). Upon Cd toxicity, the application of biofertilizer showed maximum increase in shoot and root dry weight by $115 \%$ and $112 \%$ respectively, as compared to the control (Table 5). Results in Table 5 also displayed that all the amendments had alleviating potential on Cd stress in terms of shoot and root length. Especially, the biofertilizer caused a maximum effect by $61 \%$ increase in shoot length and $26 \%$ decrease in root length, as compared to the control.

\section{Effect of biofertilizer on mineral nutrition and Cd bioaccumulation toward Cd stress}

Due to the extent of stress and growth depending on nutrient uptake and translocation, $\mathrm{Cd}$ toxicity decreased $\mathrm{N}$ and $\mathrm{P}$

content in rice shoots. Under Cd stress, all the amendments were able to maintain higher content $\mathrm{N}$ and $\mathrm{P}$ than the non-amended control (Table 6). Particularly, the biofertilizer amendment was effective in elevating maximum levels of shoot $\mathrm{N}$ and $\mathrm{P}$, as compared with the other amendments in presence of $\mathrm{Cd}$ (Table 6). This indicated that the microbial consortium in biofertilizer play a role, in part, in mitigating $\mathrm{Cd}$ toxicity in rice plant.

Table 6 also reveals the effect of biofertilizer on tissue $\mathrm{Cd}$ content. The application of biofertilizer BF significantly reduced $\mathrm{Cd}$ contents in rice root and shoot $(p<0.05)$, implying that the test biofertilizer may effectively immobilize $\mathrm{Cd}$ in soils and impair its translocation to rice tissues. This decrease in $\mathrm{Cd}$ accumulation in plants after applying the biofertilizers could be due to improved soil physical properties and nutrient availability (Table 4).

\section{Effect of biofertilizer on photosynthetic pigments in response to Cd stress}

Cd toxicity may lead to a loss of photosynthetic pigments, resulting in chlorotic symptoms. Our results showed that Cd stress caused a remarkable decrease in chlorophyll (Chl) a, Chl b, and carotenoid contents whereas the application of biofertilizer effectively suppressed these losses of pigments in presence of $\mathrm{Cd}$ (Table 7). Under Cd stress, the biofertilizer showed a maximum increase in Chl a, Chl b, total $\mathrm{Chl}$, and carotenoid synthesis by $150 \%, 125 \%, 144 \%$, and $114 \%$ respectively, as compared to the nonamended stressed control.

\section{The effect of biofertilizer on proline content and enzymatic antioxidants upon Cd stress}

Cd stress disturbed the water balance, leading to osmolyte accumulation in the rice leaves, as indicated by a great increase in proline content, but all the amendments except organic fertilizer OF suppressed the accumulation of shoot proline in comparison to the control under $\mathrm{Cd}$ stress. Cd-stressed rice seedlings 
showed a $271 \%$ increase in proline contents, as compared to the non-stressed control (Table 8). However, the biofertilizer amendment resulted in a $46 \%$ decrease in the proline synthesis, as compared to the nonamended stressed control.

Plants have vital strategies for avoidance of Cd toxicity. For the prime line on counteracting excessive ROS and serving as cellular redox buffers, the plant's antioxidant defense system consists of antioxidants that are enzymatic (e.g., superoxide dismutase SOD, ascorbate peroxidase APX, catalase CAT, and glutathione-S-transferase GST) and non-enzymatic (ascorbic acid, glutathione, tocopherol, and phenolic compounds) (Sharma et al. 2012). Both enzymatic and non-enzymatic antioxidants work simultaneously to combat the Cd-induced oxidative stress. Upon exposure to metal stress, the plant's enzymatic antioxidant activity gradually rises up with increasing metal concentration while these activities become dropped down, and enzymatic defense system is ultimately disrupted with too high metal concentration. Cd stress stimulated the activities of the antioxidant enzymes superoxide dismutase SOD and ascorbate peroxidase APX. The Cd-stressed plants showed $63 \%, 67 \%$ and $84 \%, 70 \%$ increase in SOD and APX activities of leaves and roots respectively, as compared to the non-stressed control seedling (Table 8). Under Cd stress, all the amendments except organic fertilizer OF further increased SOD and APX activity, as compared to the non-amended stressed control. In particular, application of biofertilizer BF was more effective in inducing SOD and APX activity both in roots and shoots than the other amendments. The biofertilizer amendment showed maximum SOD and APX activities by $171 \%$ and $155 \%$ in shoots and $114 \%$ and $110 \%$ in roots respectively, as compared to the control (Table 8 ). As noteworthy, the tested biofertilizer was effective in alleviating the Cd toxicity by enhancing activities of SOD and APX in rice shoots and roots.

\section{Discussion}

Among metals, $\mathrm{Cd}$ is recognized as highly toxic metal that impacts the growth and physiological processes particularly during early stages of growth and development of the plant, thereby leading to significant yield loss (Javed et al. 2019;Rizwan et al. 2017; Sarwar et al. 2015;Tanwir et al. 2015). Exposure of rice plants to $\mathrm{Cd}$ stress negatively affected the seed germination (Seang-On et al. 2019). To reduce toxicity and remediate polluted agricultural areas, soil amendments of biofertilizer containing bioagents and fertilizer are renowned with multi-modalities to enhance plant tolerance to environmental stress, nutrient supplies and biodegradation of organic matter (Chen et al. 2011). Indeed, indigenous microbial strains isolated from long-term polluted paddy site displayed resistance to $\mathrm{Cd}$ at higher levels than those isolated from unpolluted soil (Saeng-On et al. 2019). The efficiency of biofertilizers derived from indigenous $\mathrm{Cd}$-resistant microbial consortia isolated from Cd-contaminated soil in mitigating $\mathrm{Cd}$ phytotoxicity has not been well elucidated yet.

Our study firstly demonstrated that the soil amendment of biofertilizer containing indigenous cadmiumresistant microbial consortia could mitigate the adverse effect of $\mathrm{Cd}$ and improve the plant growth by restoring photosynthetic pigment losses and supplying essential nutrients in Thai rice cultivar (PSL2). Additionally, the test biofertilizer was effective to overcome water imbalance and oxidative stress by 
adjusting the proline content and the activities of antioxidant enzymes, respectively, and to limit Cd bioaccumulation by manipulating soil physicochemical traits.

\section{Bacterial composition structure of the test biofertilizers}

In the biofertilizers, Proteobacteria, Bacteroidetes, Firmicutes and Gemmatimonadetes were determined as the most dominant bacterial phyla using 16S rRNA gene Illumina MiSeq sequencing (Fig. 1). In consistent findings with related studies, the biofertilizer $\mathrm{pH}$ and organic carbon could affect the abundance of Bacteroidetes, Gemmatimonadetes and Proteobacteria, and these phyla were also dominant in biofertilizer (Wang et al. 2019). It suggested that the biofertilizer pH and organic carbon played key roles in shaping the enriched microbial communities. Moreover, bioavailability soil Cd could positively influence the microbial communities in the biofertilizer-treated soils, and some Cd-coexistence bacteria, i.e., Chloroflexi, Acidobacteria, and Saccharibacteria might have become dominant due to excess Cd in rhizosphere soils (Wang et al. 2019). In addition, the solubility and availability of soil phosphate is determined by specific microbial activities, while soil phosphate concentration becomes a determinant for Cd phytotoxicity (Wang et al. 2019).

One promising method for alleviating Cd stress and promoting plant growth is the bioaugmentation of microorganisms. For instance, the amendment of Pseudomonas aeruginosa, Bacillus subtilis, Cupriavidus taiwanensis and Beauveria bassiana to soil significantly restricted tissue Cd content in rice (Oryza sativa) and improved plant growth performance under $\mathrm{Cd}$ stress, owing to the biotransformation of the toxic Cd form to nontoxic insoluble form of $\mathrm{Cd}$ sulfide (CdS) and adsorption by Cd-binding proteins (Siripornadulsil \&Siripornadulsil 2013;Suksabye et al. 2016). Another related study showed that inoculating with plant growth-promoting rhizobacteria (PGPR) promoted maize growth and reduced shoot Cd contents compared with those of the untreated control (Moreira et al. 2014). Related findings revealed that adding Cd-resistant Micrococcus sp. TISTR2221 enhanced maize growth and retained Cd concentration in grains (Sangthong et al. 2016). Although soil microorganisms have been extensively used to promote plant performance and restrict soil $\mathrm{Cd}$, directly adding microorganisms into fields together with an appropriate organic substrate is recommended to maintain their substantial activities over a long period (Shen et al. 2015). The combined advantages of bioagents and fertilizers would be an alternative to mitigate Cd phytotoxicity.

\section{The effects of biofertilizer on soil physicochemical traits}

Our study revealed that the application of the biofertilizer BF increased soil chemical properties such as $\mathrm{pH}, \mathrm{EC}, \mathrm{CEC}$, and OM content (Table 4-1), in addition to decrease in DTPA-extractable Cd and Zn (Table 42). Mineral nutrition containing basic cations $(\mathrm{K}, \mathrm{Ca}$, and $\mathrm{Mg})$ in the biofertilizer could contribute to the increase in soil $\mathrm{pH}, \mathrm{EC}$ and $\mathrm{CEC}$, while organic residues derived from agricultural wastes were involved in nourishment of soil organic carbon. Increase in soil EC and CEC could also be regarded as key factors in modulating heavy metal exchangeability and bioavailability (Abdelhafez et al. 2014;Lu et al. 2014). Increasing soil pH after applying biofertilizer could increase the negatively charged surfaces as well as alkaline conditions, such as hydroxide and carbonate groups, which might support active substances for 
surface sorption, precipitation and complexation; thus, reducing heavy metal bioavailability with less possibility to enter the food chain (Younis et al. 2015).

Compared to the control, the application of biofertilizer BF remarkably increased soil $\mathrm{pH}$, but the amendment OF had less impact on increasing soil pH (Table 4-1). This could be due to the initial pH of the amendments (Table 2). Although applying the amendment OF had slight effect on soil pH, this amendment still decreased $\mathrm{Cd}$ contents in rice tissues compared to the control (Tables $4 \& 6$ ). These results indicated that besides $\mathrm{pH}$, the mineral nutrients, e.g., $\mathrm{N}, \mathrm{P}, \mathrm{K}, \mathrm{Ca}, \mathrm{Mg}, \mathrm{S}, \mathrm{Fe}$, and microorganisms in the biofertilizer might play crucial roles in controlling $\mathrm{Cd}$ uptake and bioaccumulation (Catherine et al. 2006; Sun et al. 2007). Related studies reported that soil pH, DTPA-extractable Cd, total phosphorus and organic carbon were determined as the most pivotal environmental factors contributing the changes in microbial community composition (Wang et al. 2019). Additionally, soil organic carbon served as the carbon source to bacteria was considered crucial. Indeed, soil pH and $\mathrm{OM}$ are considered important factors for limiting Cd availability (Khan et al. 2017;Wang et al. 2019). Moreover, potential parameters other than soil pH and $\mathrm{OM}$, including the mineral nutrition, e.g., $\mathrm{N}, \mathrm{P}, \mathrm{K}, \mathrm{Ca}, \mathrm{Mg}, \mathrm{S}, \mathrm{Fe}$, and microorganisms in the biofertilizer itself remain effective in suppressing Cd bioaccumulation (Catherine et al. 2006; Sun et al. 2007).

\section{The effects of biofertilizer on rice growth under Cd stress}

The retarded plant growth toward Cd stress might be due to various factors, where it adversely affects water status, nutrient assimilation, mineral homeostasis, photosynthesis, oxidative stress response, etc. Our study indicated that the biofertilizer BF was effective in promoting growth performance to rice plant under $\mathrm{Cd}$ stress (Table 5). This may be elucidated by the fact that beneficial microorganisms as well as mineral nutrition in the biofertilizer can facilitate $\mathrm{Cd}$ immobilization in the soil and lower its toxicity to roots; possibly allowing plants to assimilate more nutrients (Nejad et al. 2018).

\section{Effect of biofertilizer on mineral nutrition and Cd bioaccumulation toward Cd stress}

Among the other amendments, the biofertilizer BF exhibited the lowest level of tissue $\mathrm{Cd}$ as shown by decrease in shoots and roots $\mathrm{Cd}$ contents $68 \%$ and $65 \%$ respectively, compared to the non-amended control (Table 6). This might imply that the test biofertilizer had a mitigating effect on limiting Cd uptake and accumulation in rice. Due to the higher $\mathrm{pH}$ and $\mathrm{OM}$ content of the biofertilizer BF (Table $2 \& 4$ ), both of which were responsible for restricting $\mathrm{Cd}$ in soils by facilitating the generation of stable metalo-organo complexes which are more immobile at elevated pH levels (Khan et al. 2017). Cadmium is able to form $\mathrm{Cd}$ hydroxide at high soil $\mathrm{pH}(>7)$, resulting in the promotion of $\mathrm{Cd}$ adsorption to soils. Similarly, $\mathrm{OM}$ showed an effect on lowering soil Cd bioavailability and bioaccumulation in rice due to enhanced $\mathrm{Cd}$ adsorption and the formation of stable complexes with Cd (Kashem \&Singh 2001). Indeed, rice has been

regarded as a Cd-sensitive plant and an accumulator of $\mathrm{Cd}$, often containing $>0.1 \mathrm{mg} \mathrm{Cd} \mathrm{kg}^{-1}$ dry biomass (Grant et al. 2008). Indeed, the nutrients in the biofertilizer itself might also promote native microbial 
activity in the amended soils, leading to stimulated nutrient cycling, hormone production, plant symbioses and ultimately enhanced plant tolerance to stress (Farrell et al. 2009;Odlare et al. 2011).

\section{Effect of biofertilizer on photosynthetic pigments in response to Cd stress}

One of the deleterious effects due to metal stress is the remarkable destruction of photosynthetic apparatus. The reduction of chlorophyll biosynthesis and its content was observed in various plant species in response to Cd stress (Ahmad et al. 2016;Hawrylak-Nowak et al. 2015). Our study revealed a remarkable decrease in photosynthetic pigment content in terms of the $\mathrm{Chl}(\mathrm{a}+\mathrm{b})$ and carotenoid content in rice seedling leaves under $\mathrm{Cd}$ stress. These losses of pigments due to $\mathrm{Cd}$ toxicity might be a result of suppression of relevant enzymes, leading to impaired pigment biosynthesis. In addition, peroxidative breakdown of photosynthetic pigments and the chloroplast membrane lipid may occurs in response to abiotic stress due to excessive ROS (Duman et al. 2010). However, these photosynthetic pigment losses could be suppressed when applying the biofertilizer (Table 7), in consistence with previous report (Zhu et al. 2020). Alleviating Chl and carotenoid content might be linked with an increase in Cd sequestration or the pigment biosynthesis and/or decrease in the breakdown of pigment complexes (Sharma et al. 2012).

\section{The effect of biofertilizer on proline content and enzymatic antioxidants upon Cd stress}

Upon Cd stress, plants exhibit a range of secondary stress symptoms, including osmotic changes (Wang et al. 2008). Under stress, the plants utilize crucial strategies by adjusting osmolytes to alleviate the water imbalance. For instance, biosynthesis and accumulation of proline, glycine betaine, and trehalose leads to osmotic adjustment of $\mathrm{Na}^{+}$stress inside cells to equilibrate water balance (Pandey \& Gupta 2015). Our study showed an increased proline content in rice tissues under $\mathrm{Cd}$ stress, but this accumulation was suppressed by the test biofertilizer (Table 8). The exogenous application of biofertilizer could mitigate the water imbalance in Cd-stressed rice plants by modulating the biosynthesis of proline.

Recent findings have indicated that APX and SOD are regarded as prominent enzymatic antioxidant in

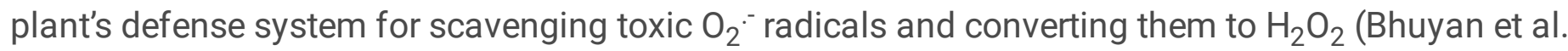
2020). The dramatical change in APX and SOD activity toward oxidative stress might be due to increased $\mathrm{O}_{2}$ - content, which was endured by the test biofertilizer (Table 8). Our findings are also in line with other previous study that reported remarkable changes in activities of APX and SOD as well as other enzymatic and non-enzymatic antioxidants in plant responses to Cd stress (Hawrylak-Nowak et al. 2015). Similarly, recent research has documented an increase in the activities of potent antioxidant enzymes APX and SOD in concentration-related manner $\left(1.0 \mathrm{mM}\right.$ and $2.0 \mathrm{mM} \mathrm{CdCl}_{2}$ respectively), as compared to the control rice seedlings (Oryza sativa L. cv. BRRI dhan54) (Bhuyan et al. 2020).

Taken together, the biofertilizer containing indigenous Cd-resistant bacterial consortium therefore appears to enhance plant growth and tolerance to Cd stress. To our investigation, the soil supplementation of the test biofertilizer BF at 3\% applied rate in Thai rice cultivar (PSL2) could mitigate Cd phytotoxicity by modulating antioxidative defense system, water and nutrient homeostasis, and restricting soil $\mathrm{Cd}$ 
bioavailability. These responses most likely reflect multi-modalities of the biofertilizer harboring such microbial detoxifiers and organic residues, where it helps adjust the antioxidative defense system and water relation together with improvement of soil biophysicochemical traits in coping with Cd toxicity in the biofertilizer-amended plant. Furthermore, the test biofertilizer may offer development of an ecofriendly sustainable strategy for improving plant fitness and soil quality rather than those using foreign strains, with practicability and simplicity.

\section{Conclusion}

Amending indigenous $\mathrm{Cd}$-resistant microbe derived-biofertilizer was effective in mitigating the $\mathrm{Cd}$ phytotoxicity by modifying the soil biophysicochemical traits to restrict the $\mathrm{Cd}$ bioavailability and enhancing plant tolerance toward environmental stress. The promoting effect of biofertilizer could be due to a rise in soil pH and enrichment of beneficial detoxifiers such as Bacteroidetes, Firmicutes and Proteobacteria in the biofertilizer, which stabilized soil $\mathrm{Cd}$ and limited its bioavailability, in addition to triggered stress-responsive modulators such as antioxidative enzymes and proline osmolyte. Our results indicated that the test biofertilizer as combined bioagents with fertilizer could not only nourish soil fertility through increasing the $\mathrm{OM}$ contents but also be served as a cost-effective amendment, especially at an applied rate to immobilize $\mathrm{Cd}$ in the polluted soil. These findings have introduced a promising mean for sustainable development of strategies in bioremediation of Cd-contaminated soils and plant growth improvement. Further study should be designated in the field setting to determine the efficiency of other crop residues and animal manure in the heavy metal decontamination in soils to reduce health risk of exposure to excessive toxic metals via the food chain resulting from anthropogenic environments.

\section{Declarations}

\section{Authors' contributions}

The funding acquisition was prepared by Preeyaporn Koedrith and Seriwat Saminpanya. The experimental conceptualization and design were conducted by Preeyaporn Koedrith. Methodology, material preparation, data collection and analysis were performed by Ladda Seang-On and Preeyaporn Koedrith. The first draft of the manuscript was written by Preeyaporn Koedrith with suggestion by Weeradej Meeinkuirt. All authors read and approved the final manuscript.

\section{Funding information}

This work was supported by a grant from Mahidol University, Thailand under the program titled, "Stabilization and bioremediation of cadmium- and zinc-contaminated soil for sustainable rice cultivation" from the National Research Council of Thailand.

\section{Data availability}


All data generated or analyzed during this study are included in this published article and information files.

Ethics approval and consent to participate Not applicable.

Consent for publication Not applicable.

Completing interests The authors declare no completing interests.

\section{References}

1. Abdelhafez AA, Li J, Abbas MH (2014) Feasibility of biochar manufactured from organic wastes on the stabilization of heavy metals in a metal smelter contaminated soil. Chemosphere 117: 66-71.

2. Ahemad M, Khan MS (2012a) Ecological assessment of biotoxicity of pesticides towards plant growth promoting activities of pea (Pisum sativum)-specific rhizobium SP. STRAINMRP1. Emir J Food Agric 334-343. 334-343.

3. Ahemad M, Khan MS (2012b) Effect of fungicides on plant growth promoting activities of phosphate solubilizing Pseudomonas putida isolated from mustard (Brassica compestris) rhizosphere. Chemosphere 86: 945-950.

4. Ahemad M, Khan MS (2012c)Evaluation of plant-growth-promoting activities of rhizobacterium Pseudomonas putida under herbicide stress. Annals of microbiology 62: 1531-1540.

5. Ahemad M, Khan MS (2012d) Alleviation of fungicide-induced phytotoxicity in greengram [Vigna radiata (L.) Wilczek] using fungicide-tolerant and plant growth promoting Pseudomonas strain. Saudi J Biol Sci 19: 451-459.

6. Ahmad P, Abd Allah E, Hashem A, Sarwat M, Gucel S (2016) Exogenous application of selenium mitigates cadmium toxicity in Brassica juncea L.(Czern \& Cross) by up-regulating antioxidative system and secondary metabolites. J Plant Growth Regul 35: 936-950.

7. Asada K (1987) Production and scavenging of active oxygen in photosynthesis. Photoinhibition 227287. 227-287.

8. Bates LS, Waldren RP, Teare I (1973) Rapid determination of free proline for water-stress studies. Plant and soil 39: 205-207.

9. Beyer Jr WF, Fridovich I (1987) Assaying for superoxide dismutase activity: some large consequences of minor changes in conditions. Anal Biochem 161: 559-566.

10. Bhardwaj D, Ansari MW, Sahoo RK, Tuteja N (2014) Biofertilizers function as key player in sustainable agriculture by improving soil fertility, plant tolerance and crop productivity. Microb Cell Fact 13: 1-10.

11. Bhuyan M, Parvin K, Mohsin SM, Mahmud JA, Hasanuzzaman M, Fujita M (2020) Modulation of cadmium tolerance in rice: Insight into vanillic acid-induced upregulation of antioxidant defense and glyoxalase systems. Plants 9: 188. 
12. Bray RH, Kurtz LT (1945) Determination of total, organic, and available forms of phosphorus in soils. Soil science 59: 39-46.

13. Burnison BK (1980) Modified dimethyl sulfoxide (DMSO) extraction for chlorophyll analysis of phytoplankton.

14. Can J Fish Aquat Sci 37: 729-733.

15. Caporaso JG, Kuczynski J, Stombaugh J, Bittinger K, Bushman FD, Costello EK, Fierer N, Peña AG, Goodrich JK, Gordon JI (2010) QIIME allows analysis of high-throughput community sequencing data. Nature methods 7: 335-336.

16. Catherine S, Christophe S, Louis MJ (2006) Response of Thlaspi caerulescens to nitrogen, phosphorus and sulfur fertilisation. Int J Phytoremediation 8: 149-161.

17. Cazorla F, Romero D, Pérez-García A, Lugtenberg B, Vicente Ad, Bloemberg G (2007) Isolation and characterization of antagonistic Bacillus subtilis strains from the avocado rhizoplane displaying biocontrol activity. J Appl Microbiol 103: 1950-1959.

18. Chen L, Yang X, Raza W, Luo J, Zhang F, Shen Q (2011) Solid-state fermentation of agro-industrial wastes to produce bioorganic fertilizer for the biocontrol of Fusarium wilt of cucumber in continuously cropped soil. Bioresource Technology 102: 3900-3910.

19. Deng R, Huang D, Zeng G, Wan J, Xue W, Wen X, Liu X, Chen S, Li J, Liu C (2019) Decontamination of lead and tetracycline from aqueous solution by a promising carbonaceous nanocomposite: Interaction and mechanisms insight. Bioresource technology 283: 277-285.

20. Deng R, Huang D, Xue W, Lei L, Zhou C, Chen S, Wen X, Liu X (2020) How does the microenvironment change during the stabilization of cadmium in exogenous remediation sediment? J Hazard Mater 398: 122836.

21. Din BU, Rafique M, Javed MT, Kamran MA, Mehmood S, Khan M, Sultan T, Munis MFH, Chaudhary HJ (2020) Assisted phytoremediation of chromium spiked soils by Sesbania sesban in association with Bacillus xiamenensis PM14: A biochemical analysis. Plant physiology and biochemistry 146: 249-258.

22. Duman F, Ozturk F, Aydin Z (2010) Biological responses of duckweed (Lemna minor L.) exposed to the inorganic arsenic species As (III) and As (V): effects of concentration and duration of exposure. Ecotoxicology 19: 983-993.

23. Edgar RC, Haas BJ, Clemente JC, Quince C, Knight R (2011) UCHIME improves sensitivity and speed of chimera detection. Bioinformatics 27: 2194-2200.

24. Farrell M, Griffith GW, Hobbs PJ, Perkins WT, Jones DL (2009) Microbial diversity and activity are increased by compost amendment of metal-contaminated soil. FEMS Microbiol Ecol 71: 94-105.

25. Gajdos É, Lévai L, Veres S, Kovács B (2012) Effects of biofertilizers on maize and sunflower seedlings under cadmium stress. Commun Soil Sci Plant Anal 43: 272-279.

26. Gill RA, Zhang N, Ali B, Farooq MA, Xu J, Gill MB, Mao B, Zhou W (2016) Role of exogenous salicylic acid in regulating physio-morphic and molecular changes under chromium toxicity in black-and yellow-seeded Brassica napus L. Environ Sci Pollut Res 23: 20483-20496. 
27. Glick BR (2012) Plant growth-promoting bacteria: mechanisms and applications. Scientifica 2012

28. Govindasamy V, Senthilkumar M, Bose P, Kumar LV, Ramadoss D, Annapurna K (2011) ACC deaminase containing PGPR for potential exploitation in agriculture, Bacteria in Agrobiology: Plant Nutrient Management. Springer, pp. 183-208

29. Grant CA, Clarke JM, Duguid S, Chaney R (2008) Selection and breeding of plant cultivars to minimize cadmium accumulation. Sci Total Environ 390: 301-310.

30. Hawrylak-Nowak B, Dresler S, Matraszek R (2015) Exogenous malic and acetic acids reduce cadmium phytotoxicity and enhance cadmium accumulation in roots of sunflower plants. Plant Physiol Biochem 94: 225-234.

31. Herlemann DP, Labrenz M, Jürgens K, Bertilsson S, Waniek JJ, Andersson AF (2011) Transitions in bacterial communities along the $2000 \mathrm{~km}$ salinity gradient of the Baltic Sea. The ISME journal 5: 1571-1579.

32. Jahanian A, Chaichi M, Rezaei K, Rezayazdi K, Khavazi K (2012) The effect of plant growth promoting rhizobacteria (PGPR) on germination and primary growth of artichoke (Cynara scolymus). Int Agric Crop Sci (IJACS) 4: 923-929.

33. Javed MT, Tanwir K, Akram MS, Shahid M, Niazi NK, Lindberg S (2019): Phytoremediation of cadmium-polluted water/sediment by aquatic macrophytes: role of plant-induced $\mathrm{pH}$ changes, cadmium toxicity and tolerance in plants. Elsevier, pp. 495-529

34. Jha PN, Kumar A (2007) Endophytic colonization of Typha australis by a plant growth-promoting bacterium Klebsiella oxytoca strain GR-3. J Appl Microbiol 103: 1311-1320.

35. Kashem M, Singh B (2001) Metal availability in contaminated soils: I. Effects of flooding and organic matter on changes in Eh, pH and solubility of Cd, Ni andZn. Nutr Cycl Agroecosyst 61: 247-255.

36. Khan AG (2005) Role of soil microbes in the rhizospheres of plants growing on trace metal contaminated soils in phytoremediation. J Trace Elem Med Biol 18: 355-364.

37. Khan MA, Khan S, Khan A, Alam M (2017) Soil contamination with cadmium, consequences and remediation using organic amendments. J Total Environ 601: 1591-1605.

38. Lowry OH, Rosebrough NJ, Farr AL, Randall RJ (1951) Protein measurement with the Folin phenol reagent. J Biol Chem 193: 265-275.

39. Lu K, Yang X, Shen J, Robinson B, Huang H, Liu D, Bolan N, Pei J, Wang H (2014) Effect of bamboo and rice straw biochars on the bioavailability of $\mathrm{Cd}, \mathrm{Cu}, \mathrm{Pb}$ and $\mathrm{Zn}$ to Sedum plumbizincicola. Agric Ecosyst Environ 191: 124-132.

40. Lux A, Martinka M, Vaculík M, White PJ (2011) Root responses to cadmium in the rhizosphere: a review. J Exp Bot 62: 21-37.

41. Madhaiyan M, Poonguzhali S, Sa T (2007) Metal tolerating methylotrophic bacteria reduces nickel and cadmium toxicity and promotes plant growth of tomato (Lycopersicon esculentum L.). Chemosphere 69: 220-228. 
42. Moreira H, Marques AP, Franco AR, Rangel AO, Castro PM (2014) Phytomanagement of Cdcontaminated soils using maize (Zea mays L.) assisted by plant growth-promoting rhizobacteria. Environ Sci Pollut Res 21: 9742-9753.

43. Nejad ZD, Jung MC, Kim K-H (2018) Remediation of soils contaminated with heavy metals with an emphasis on immobilization technology. Environ Geochem Health 40: 927-953.

44. Nelson DW, Sommers LE (1996) Total carbon, organic carbon, and organic matter. Methods of soil analysis: Part 3 Chemical methods 5: 961-1010.

45. Odlare M, Arthurson V, Pell M, Svensson K, Nehrenheim E, Abubaker J (2011) Land application of organic waste-effects on the soil ecosystem. Appl Energy 88: 2210-2218.

46. Oorts K, Ghesquiere U, Smolders E (2007) Leaching and aging decrease nickel toxicity to soil microbial processes in soils freshly spiked with nickel chloride. Environ Toxicol Chem: Int J 26: 11301138.

47. Pandey C, Gupta M (2015) Selenium and auxin mitigates arsenic stress in rice (Oryza sativa L.) by combining the role of stress indicators, modulators and genotoxicity assay. J hazard Mate 287: 384391.

48. Rafique M, Ortas I, Rizwan M, Sultan T, Chaudhary HJ, Işik M, Aydin O (2019) Effects of Rhizophagus clarus and biochar on growth, photosynthesis, nutrients, and cadmium (Cd) concentration of maize (Zea mays) grown in Cd-spiked soil. Environ Sci Pollut Res 26: 20689-20700.

49. Rajkumar M, Ae N, Prasad MNV, Freitas H (2010) Potential of siderophore-producing bacteria for improving heavy metal phytoextraction. Trends in biotechnology 28: 142-149.

50. Rizwan M, Ali S, Hussain A, Ali Q, Shakoor MB, Zia-ur-Rehman M, Farid M, Asma M (2017) Effect of zinc-lysine on growth, yield and cadmium uptake in wheat (Triticum aestivum L.) and health risk assessment. Chemosphere 187: 35-42.

51. Rodrigues EP, Rodrigues LdS, de Oliveira ALM, Baldani VLD, dos Santos Teixeira KR, Urquiaga S, Reis VM (2008) Azospirillum amazonense inoculation: effects on growth, yield and $\mathrm{N}_{2}$ fixation of rice (Oryza sativa L.). Plant and Soil 302: 249-261.

52. Sangthong C, Setkit K, Prapagdee B (2016) Improvement of cadmium phytoremediation after soil inoculation with a cadmium-resistant Micrococcus sp. Environ Sci Pollut Res 23: 756-764.

53. Saravanakumar D, Vijayakumar C, Kumar N, Samiyappan R (2007) PGPR-induced defense responses in the tea plant against blister blight disease. Crop protection 26: 556-565.

54. Sarwar N, Ishaq W, Farid G, Shaheen MR, Imran M, Geng M, Hussain S (2015) Zinc-cadmium interactions: Impact on wheat physiology and mineral acquisition. Ecotoxicol Environ Saf 122: 528536.

55. Schloss PD, Westcott SL, Ryabin T, Hall JR, Hartmann M, Hollister EB, Lesniewski RA, Oakley BB, Parks DH, Robinson CJ (2009) Introducing mothur: open-source, platform-independent, communitysupported software for describing and comparing microbial communities. Appl Environ Microbiol 75: 7537-7541. 
56. Seang-On L, Meeinkuirt W, Saengwilai P, Saminpanya S, Koedrith K (2019) Alleviation of cadmium stress in Thai rice cultivar (PSL2) by inoculation of indigenous cadmium-resistant microbial consortia. Appl Ecol Environ Res 17: 14679-14697.

57. Shah AA, Ahmed S, Ali A, Yasin NA (2020) 2-Hydroxymelatonin mitigates cadmium stress in Cucumis sativus seedlings: Modulation of antioxidant enzymes and polyamines. Chemosphere 243: 125308.

58. Sharma P, Jha AB, Dubey RS, Pessarakli M (2012) Reactive oxygen species, oxidative damage, and antioxidative defense mechanism in plants under stressful conditions. J Bot 2012: 217037.

59. Shen Z, Zhong S, Wang Y, Wang B, Mei X, Li R, Ruan Y, Shen Q (2013) Induced soil microbial suppression of banana Fusarium wilt disease using compost and biofertilizers to improve yield and quality. Eur J Soil Biol 57: 1-8.

60. Shen Z, Ruan Y, Chao X, Zhang J, Li R, Shen Q (2015) Rhizosphere microbial community manipulated by 2 years of consecutive biofertilizer application associated with banana Fusarium wilt disease suppression. Biol Fertil Soils 51: 553-562.

61. Simmons RW, Pongsakul P, Chaney R, Saiyasitpanich D, Klinphoklap S, Nobuntou W (2003) The relative exclusion of zinc and iron from rice grain in relation to rice grain cadmium as compared to soybean: Implications for human health. Plant and Soil 257: 163-170.

62. Simmons RW, Pongsakul P, Saiyasitpanich D, Klinphoklap S (2005) Elevated levels of cadmium and zinc in paddy soils and elevated levels of cadmium in rice grain downstream of a zinc mineralized area in Thailand: implications for public health. Environ Geochem Health 27: 501-511.

63. Siripornadulsil S, Siripornadulsil W (2013) Cadmium-tolerant bacteria reduce the uptake of cadmium in rice: potential for microbial bioremediation. Ecotoxicol Environ Saf 94: 94-103.

64. Suksabye P, Pimthong A, Dhurakit P, Mekvichitsaeng P, Thiravetyan P (2016) Effect of biochars and microorganisms on cadmium accumulation in rice grains grown in Cd-contaminated soil. Environ Sci Pollut Res 23: 962-973.

65. Sun L, Niu Z, Sun T (2007) Effects of amendments of N, P, Fe on phytoextraction of Cd, Pb, Cu, and $\mathrm{Zn}$ in soil of Zhangshi by mustard, cabbage, and sugar beet. Environ Toxic: Intern J 22: 565-571.

66. Swaddiwudhipong W, Limpatanachote P, Mahasakpan P, Krintratun S, Punta B, Funkhiew T (2012) Progress in cadmium-related health effects in persons with high environmental exposure in northwestern Thailand: a five-year follow-up. Environ Res 112: 194-198.

67. Tank N, Saraf M (2010) Salinity-resistant plant growth promoting rhizobacteria ameliorates sodium chloride stress on tomato plants. J Plant Interact 5: 51-58.

68. Tanwir K, Akram MS, Masood S, Chaudhary HJ, Lindberg S, Javed MT (2015) Cadmium-induced rhizospheric $\mathrm{pH}$ dynamics modulated nutrient acquisition and physiological attributes of maize (Zea mays L.). Environ Sci Pollut Res 22: 9193-9203.

69. Tchounwou PB, Yedjou CG, Patlolla AK, Sutton DJ (2012) Heavy metal toxicity and the environment. Molecular, clinical and environmental toxicology133-164. 133-164.

70. Tian F, Ding Y, Zhu H, Yao L, Du B (2009) Genetic diversity of siderophore-producing bacteria of tobacco rhizosphere. Braz J Microbiol 40: 276-284. 
71. Wang M, Li S, Chen S, Meng N, Li X, Zheng H, Zhao C, Wang D (2019) Manipulation of the rhizosphere bacterial community by biofertilizers is associated with mitigation of cadmium phytotoxicity. Sci Total Environ 649: 413-421.

72. Wang Z, Zhang Y, Huang Z, Huang L (2008) Antioxidative response of metal-accumulator and nonaccumulator plants under cadmium stress. Plant and soil 310: 137-149.

73. Wani PA, Khan MS (2010) Bacillus species enhance growth parameters of chickpea (Cicer arietinum L.) in chromium stressed soils. Food Chem Toxicol 48: 3262-3267.

74. Younis U, Qayyum MF, Shah MHR, Danish S, Shahzad AN, Malik SA, Mahmood S (2015) Growth, survival, and heavy metal ( $\mathrm{Cd}$ and $\mathrm{Ni}$ ) uptake of spinach (Spinacia oleracea) and fenugreek (Trigonella corniculata) in a biochar-amended sewage-irrigated contaminated soil. J Plant Nutr Soil Sci 178: 209-217.

75. Zhu Y, Wang H, Lv X, Zhang Y, Wang W (2020) Effects of biochar and biofertilizer on cadmiumcontaminated cotton growth and the antioxidative defense system. Sci Rep 10: 20112.

\section{Tables}

Table 1 Experimental treatments and their nomenclature used in this study.

Symbol Treatments

CK Non-amended plants under normal condition

CD Non-amended plants under Cd stress

OF.D Plants amended with organic fertilizer (OF) under Cd stress

BC.D Plants inoculated with indigenous Cd-resistant bacterial consortium (BC) under Cd stress

BF.D Plants amended with biofertilizer (BF) containing indigenous Cd-resistant bacterial consortium under Cd stress

Table 2 Physicochemical properties and bacterial composition in phyla of biofertilizer 


\begin{tabular}{|c|c|c|c|}
\hline Biofertilizer & & $\mathrm{BF}$ & OF \\
\hline Total viable count (CFU g $\left.{ }^{-1}\right)$ & & $7.8 \times 10^{8}$ & - \\
\hline \multirow[t]{7}{*}{ Bacterial composition in phyla (\%) } & Acidobacteria & 1.46 & - \\
\hline & Bacteriodetes & 25.89 & - \\
\hline & Firmicutes & 55.45 & - \\
\hline & Gemmatimonadetes & 0.12 & - \\
\hline & Proteobacteria & 16.69 & - \\
\hline & Planctomycetes & 0.27 & - \\
\hline & Others & 0.12 & - \\
\hline $\mathrm{pH}$ & & 8.07 & 7.14 \\
\hline $\mathrm{OM}\left(\mathrm{mg} \mathrm{kg}^{-1}\right)$ & & 4035 & 3046 \\
\hline $\mathrm{N}\left(\mathrm{mg} \mathrm{kg}^{-1}\right)$ & & 618 & 814 \\
\hline$P\left(\mathrm{mg} \mathrm{kg}^{-1}\right)$ & & 922 & 611 \\
\hline $\mathrm{K}\left(\mathrm{mg} \mathrm{kg}^{-1}\right)$ & & 1205 & 761 \\
\hline $\mathrm{Ca}\left(\mathrm{mg} \mathrm{kg}^{-1}\right)$ & & 84 & 107 \\
\hline $\mathrm{Mg}\left(\mathrm{mg} \mathrm{kg}^{-1}\right)$ & & 82 & 98 \\
\hline $\mathrm{S}\left(\mathrm{mg} \mathrm{kg}^{-1}\right)$ & & 28 & 22 \\
\hline $\mathrm{Fe}\left(\mathrm{mg} \mathrm{kg}^{-1}\right)$ & & 39 & 35 \\
\hline $\mathrm{Mn}\left(\mathrm{mg} \mathrm{kg}^{-1}\right)$ & & 2.3 & 5.13 \\
\hline $\mathrm{Zn}\left(\mathrm{mg} \mathrm{kg}^{-1}\right)$ & & 3.2 & 4.8 \\
\hline $\mathrm{Cd}\left(\mathrm{mg} \mathrm{kg}^{-1}\right)$ & & ND & ND \\
\hline
\end{tabular}

Note: $\mathrm{pH}$ (1:5 soil/water); CEC cation exchange capacity; OM organic matter; Total $\mathrm{N}$ total nitrogen; Ext. $\mathrm{P}$ extractable phosphorus; Ext. K extractable potassium; Ca Calcium; Mg Magnesium; S Sulfur; Fe Iron; Mn Manganese; Zn Zinc; Cd Cadmium; ND not detectable; BF biofertilizer containing indigenous Cd-resistant bacterial consortium; OF organic fertilizer as amendment control.

Table 3 Summary of 16S rRNA gene Illumina MiSeq sequencing data and diversity estimates for each sample 


\begin{tabular}{|lllllll|}
\hline Sample & Process & Reads & OTUs & Coverage & Chao1 & Shannon \\
\hline BC\#1 & Enrichment & $60999 \pm 8307$ & $3042 \pm 198$ & 0.998 & 1514.74 & 4.60 \\
\hline BC\#2 & Enrichment & $61629 \pm 5829$ & $3021 \pm 314$ & 0.998 & 1670.77 & 4.54 \\
\hline BC\#3 & Enrichment & $61347 \pm 6018$ & $3092 \pm 268$ & 0.997 & 1497.53 & 4.76 \\
\hline BF\#1 & Biofertilization & $61034 \pm 8109$ & $3008 \pm 229$ & 0.996 & $5451.82^{\star \star}$ & $10.72^{\star \star}$ \\
\hline BF\#2 & Biofertilization & $62182 \pm 6102$ & $3034 \pm 312$ & 0.997 & $5515.27^{\star \star}$ & $10.83^{\star \star}$ \\
\hline BF\#3 & Biofertilization & $63179 \pm 7019$ & $3063 \pm 251$ & 0.998 & $5672.43^{\star \star}$ & $10.92^{\star \star}$ \\
\hline
\end{tabular}

Note: $* *$ Indicates respective significant difference at $p$-value $\leq 0.05$, by comparing the selected parameters (Chao1

richness or Shannon diversity estimator) of the bacterial enriched consortia to that of the corresponding biofertilizers. OTUs operational taxonomic units; BC Cd-resistant bacterial consortia after Cdsupplemented culture

enrichment of the naturally polluted topsoil samples; BF biofertilizers after semi-solid state fermentation process of

the corresponding enriched consortium.

Table 4-1 Effect of biofertilizer containing indigenous Cd-resistant bacterial consortium on soil physicochemical properties in potting system after plantation under $\mathrm{Cd}$ stress 
Treatment

$\begin{array}{lll}\mathrm{pH} & \mathrm{EC} & \mathrm{CEC} \\ & & \\ & \left(\mathrm{dS} \mathrm{m}^{-}\right. & \left(\mathrm{cmol} \mathrm{kg}^{-}\right. \\ & 1) & 1)\end{array}$

OM Total $\mathrm{N}\left(\mathrm{mg} \mathrm{kg}{ }^{-} \quad\right.$ Ext. $\mathrm{P}$

(\%) 1 ) (mg kgExt. $\mathrm{K}\left(\mathrm{mg} \mathrm{kg}^{-}\right.$ 1)

1)

Before

planting

$\begin{array}{llllllll}\text { CD } & 6.65 & 0.27^{\mathrm{a}} & 10.4^{\mathrm{a}} & 1.09^{\mathrm{a}} & 2118^{\mathrm{a}} & 8.7^{\mathrm{a}} & 164.3^{\mathrm{a}}\end{array}$

After planting

\begin{tabular}{lccccccc} 
CD & 6.47 & $0.12^{\mathrm{b}}$ & $9.5^{\mathrm{a}}$ & $1.18^{\mathrm{a}}$ & $2202^{\mathrm{a}}$ & $9.4^{\mathrm{a}}$ & $153.4^{\mathrm{a}}$ \\
\hline OF.D & 6.93 & $0.54^{\mathrm{c}}$ & $15.8^{\mathrm{b}}$ & $2.47^{\mathrm{b}}$ & $6229^{\mathrm{b}}$ & $19.4^{\mathrm{b}}$ & $212.4^{\mathrm{a}}$ \\
\hline BC.D & 6.97 & $0.78^{\mathrm{c}}$ & $16.6^{\mathrm{b}}$ & $2.38^{\mathrm{b}}$ & $6083^{\mathrm{b}}$ & $20.9^{\mathrm{b}}$ & $206.8^{\mathrm{a}}$ \\
\hline BF.D & 7.83 & $1.68^{\mathrm{d}}$ & $19.8^{\mathrm{b}}$ & $2.93^{\mathrm{b}}$ & $7645^{\mathrm{b}}$ & $25.8^{\mathrm{b}}$ & $298.5^{\mathrm{b}}$
\end{tabular}

Note: All the values are the mean of three replicates \pm standard error of means. Different lowercase letters indicate statistically significant difference between treatments $(p \leq 0.05)$. Details of treatments as given in Table 1. BC Cd-resistant bacterial consortium after culture enrichment; BF Biofertilizer containing indigenous Cd-resistant bacterial consortium; OF organic fertilizer as amendment control; pH (1:5 soil/water); EC electrical conductivity; CEC cation exchange capacity; OM organic matter; Total $\mathrm{N}$ total nitrogen; Ext. P extractable phosphorus; Ext. K extractable potassium.

Table 4-2 Effect of biofertilizer containing indigenous Cd-resistant bacterial consortium on soil $\mathrm{Cd}$ and $\mathrm{Zn}$ content in potting system after plantation under Cd stress

\begin{tabular}{llllll} 
Treatment & $\mathrm{pH}$ & $\begin{array}{c}\text { Total Cd } \\
\left(\mathrm{mg} \mathrm{kg}^{-1}\right)\end{array}$ & $\begin{array}{l}\text { Ext. Cd } \\
\left(\mathrm{mg} \mathrm{kg}^{-1}\right)\end{array}$ & $\begin{array}{l}\text { Total Zn } \\
\left(\mathrm{mg} \mathrm{kg}^{-1}\right)\end{array}$ & $\begin{array}{l}\text { Ext. Zn } \\
\left(\mathrm{mg} \mathrm{kg}^{-1}\right)\end{array}$ \\
\hline Before planting & & & & & \\
\hline CD & 6.65 & $69.1 \pm 10.3^{\mathrm{a}}$ & $8.91 \pm 0.22^{\mathrm{a}}$ & $729.5 \pm 62.3^{\mathrm{a}}$ & $117.8 \pm 18.6^{\mathrm{a}}$ \\
\hline After planting & & & & & \\
\hline CD & 6.47 & $68.4 \pm 11.2^{\mathrm{a}}$ & $8.84 \pm 0.19^{\mathrm{a}}$ & $718.8 \pm 69.9^{\mathrm{a}}$ & $108.7 \pm 21.6^{\mathrm{a}}$ \\
\hline OF.D & 6.93 & $36.4 \pm 10.5^{\mathrm{b}}$ & $4.89 \pm 0.21^{\mathrm{b}}$ & $464.2 \pm 50.2^{\mathrm{b}}$ & $68.5 \pm 13.5^{\mathrm{b}}$ \\
\hline BC.D & 6.97 & $30.4 \pm 10.7^{\mathrm{b}}$ & $4.17 \pm 0.23^{\mathrm{b}}$ & $338.8 \pm 45.5^{\mathrm{b}}$ & $53.7 \pm 11.4^{\mathrm{b}}$ \\
\hline BF.D & 7.83 & $22.4 \pm 8.6^{\mathrm{b}}$ & $4.03 \pm 0.16^{\mathrm{b}}$ & $302.2 \pm 53.3^{\mathrm{b}}$ & $45.8 \pm 12.6^{\mathrm{b}}$
\end{tabular}


Note: All the values are the mean of three replicates \pm standard error of means. Different lowercase letters indicate statistically significant difference between treatments $(p \leq 0.05)$. Details of treatments as given in Table 1. BC Cd-resistant bacterial consortium after culture enrichment; BF Biofertilizer containing indigenous Cd-resistant bacterial consortium; OF organic fertilizer as amendment control; Total Cd total cadmium; Ext. Cd extractable cadmium; Total Zn total zinc; Ext. Zn extractable zinc.

Table 5 Effect of biofertilizer containing indigenous Cd-resistant microbial consortia on the biomass and length of shoot and roots of PSL2 Thai rice cultivar grown in Cd-enriched soils in potting system over 4 months

\begin{tabular}{lllll} 
Treatment & $\begin{array}{l}\text { Shoot DW } \\
(\text { mg plant } \\
1\end{array}$ & $\begin{array}{l}\text { Root DW } \\
\left(\mathrm{mg} \mathrm{plant}^{-1}\right)\end{array}$ & $\begin{array}{l}\text { Shoot length (cm in } \\
\text { average) }\end{array}$ & $\begin{array}{l}\text { Root length (cm in } \\
\text { average) }\end{array}$ \\
\hline CK & $76.4 \pm 4.8^{\mathrm{a}}$ & $149.3 \pm 1.8^{\mathrm{a}}$ & $45.2 \pm 7.0^{\mathrm{a}}$ & $24.6 \pm 4.8^{\mathrm{a}}$ \\
\hline CD & $35.1 \pm 2.8^{\mathrm{b}}$ & $78.2 \pm 3.8^{\mathrm{b}}$ & $29.3 \pm 5.8^{\mathrm{b}}$ & $49.1 \pm 8.4^{\mathrm{b}}$ \\
\hline OF.D & $58.7 \pm 1.7^{\mathrm{a}}$ & $127.4 \pm 5.2^{\mathrm{a}}$ & $37.6 \pm 5.5^{\mathrm{a}}$ & $45.1 \pm 5.3^{\mathrm{b}}$ \\
\hline BC.D & $64.5 \pm 3.5^{\mathrm{a}}$ & $138.3 \pm 7.1^{\mathrm{a}}$ & $39.2 \pm 5.2^{\mathrm{a}}$ & $40.9 \pm 6.1^{\mathrm{b}}$ \\
\hline BF.D & $75.3 \pm 1.4^{\mathrm{a}}$ & $165.7 \pm 8.2^{\mathrm{a}}$ & $47.2 \pm 8.2^{\mathrm{a}}$ & $36.5 \pm 7.3^{\mathrm{b}}$
\end{tabular}

Note: All the values are the mean of three replicates \pm standard error of means. Different lowercase letters indicate statistically significant difference between treatments $(p \leq 0.05)$. Details of treatments as given in Table 1. BC Cd-resistant bacterial consortium after culture enrichment; BF Biofertilizer containing indigenous Cd-resistant bacterial consortium; OF organic fertilizer as amendment control; DW dry weight;

Table 6 Effect of biofertilizer containing indigenous Cd-resistant microbial consortia on the mineral nutrition (shoot nitrogen and phosphorus content) and tissue Cd content of PSL2 Thai rice cultivar grown in Cd-enriched soils in potting system 
Treatment Shoot N content Shoot P content Shoot Cd content Root Cd content

\begin{tabular}{lllll} 
& $\left(\mathrm{mg} \mathrm{plant}^{-1}\right)$ & $\left(\mathrm{mg} \mathrm{plant}^{-1}\right)$ & $\left(\mathrm{mg} \mathrm{kg}^{-1}\right)$ & $\left(\mathrm{mg} \mathrm{kg}^{-1}\right)$ \\
\hline CK & $9.4 \pm 0.8^{\mathrm{a}}$ & $4.3 \pm 0.6^{\mathrm{a}}$ & $\mathrm{ND}$ & $\mathrm{ND}$ \\
\hline $\mathrm{CD}$ & $3.2 \pm 0.7^{\mathrm{b}}$ & $1.9 \pm 0.4^{\mathrm{b}}$ & $10.9 \pm 2.1^{\mathrm{a}}$ & $403.2 \pm 87.6^{\mathrm{a}}$ \\
\hline OF.D & $18.7 \pm 3.5^{\mathrm{c}}$ & $8.5 \pm 1.1^{\mathrm{c}}$ & $5.1 \pm 1.6^{\mathrm{b}}$ & $232.9 \pm 63.5^{\mathrm{b}}$ \\
\hline BC.D & $21.5 \pm 1.3^{\mathrm{c}}$ & $10.9 \pm 1.4^{\mathrm{c}}$ & $4.3 \pm 1.8^{\mathrm{b}}$ & $165.3 \pm 81.3^{\mathrm{b}}$ \\
\hline BF.D & $24.9 \pm 3.1^{\mathrm{c}}$ & $12.9 \pm 1.8^{\mathrm{c}}$ & $3.4 \pm 1.1^{\mathrm{b}}$ & $139.4 \pm 71.6^{\mathrm{b}}$
\end{tabular}

Note: All the values are the mean of three replicates \pm standard error of means. Different lowercase letters indicate statistically significant difference between treatments $(p \leq 0.05)$. Details of treatments as given in Table 1. BC Cd-resistant bacterial consortium after culture enrichment; BF Biofertilizer containing indigenous $\mathrm{Cd}$-resistant bacterial consortium; OF organic fertilizer as amendment control; $\mathrm{N}$ nitrogen; $\mathrm{P}$ phosphorus; ND not detectable.

Table 7 Effect of biofertilizer indigenous containing Cd-resistant microbial consortia on the photosynthetic pigments (chlorophyll $a$ and $b$ and carotenoids content) of PSL2 Thai rice cultivar grown in Cd-enriched soils in potting system

\begin{tabular}{lllll} 
Treatment & $\begin{array}{l}\text { Chl a } \\
\left(\mathrm{mg} \mathrm{g}^{-1} \mathrm{FW}\right)\end{array}$ & $\begin{array}{l}\mathrm{Chl} \mathrm{b} \\
\left(\mathrm{mg} \mathrm{g}^{-1} \mathrm{FW}\right)\end{array}$ & $\begin{array}{l}\text { Total Chl } \\
\left(\mathrm{mg} \mathrm{g}^{-1} \mathrm{FW}\right)\end{array}$ & $\begin{array}{l}\text { Carotenoid } \\
\left(\mathrm{mg} \mathrm{g}^{-1} \mathrm{FW}\right)\end{array}$ \\
\hline $\mathrm{CK}$ & $1.6 \pm 0.3^{\mathrm{a}}$ & $1.0 \pm 0.1^{\mathrm{a}}$ & $2.6 \pm 0.3^{\mathrm{a}}$ & $1.8 \pm 0.5^{\mathrm{a}}$ \\
\hline $\mathrm{CD}$ & $0.6 \pm 0.2^{\mathrm{b}}$ & $0.4 \pm 0.1^{\mathrm{b}}$ & $1.0 \pm 0.2^{\mathrm{b}}$ & $0.7 \pm 0.2^{\mathrm{b}}$ \\
\hline OF.D & $1.0 \pm 0.5^{\mathrm{a}}$ & $0.6 \pm 0.2^{\mathrm{a}}$ & $1.6 \pm 0.4^{\mathrm{a}}$ & $1.1 \pm 0.3^{\mathrm{a}}$ \\
\hline BC.D & $1.2 \pm 0.2^{\mathrm{a}}$ & $0.8 \pm 0.1^{\mathrm{a}}$ & $2.0 \pm 0.2^{\mathrm{a}}$ & $1.3 \pm 0.2^{\mathrm{a}}$ \\
\hline BF.D & $1.5 \pm 0.8^{\mathrm{a}}$ & $0.9 \pm 0.2^{\mathrm{a}}$ & $2.4 \pm 0.7^{\mathrm{a}}$ & $1.5 \pm 0.3^{\mathrm{a}}$
\end{tabular}

Note: All the values are the mean of three replicates \pm standard error of means. Different lowercase letters indicate statistically significant difference between treatments $(p \leq 0.05)$. Details of treatments as given in Table 1. BC Cd-resistant bacterial consortium after culture enrichment; BF Biofertilizer containing indigenous Cd-resistant bacterial consortium; OF organic fertilizer as amendment control; Chl chlorophyll; Total $\mathrm{Chl}=\mathrm{Chl}(\mathrm{a}+\mathrm{b}) ; \mathrm{FW}$ fresh weight.

Table 8 Effect of biofertilizer containing indigenous Cd-resistant microbial consortia on the physiological modulators (proline content and enzymatic antioxidant activities of SOD and APX) of PSL2 Thai rice 
seedling grown in Cd-enriched soils in potting system

\begin{tabular}{|c|c|c|c|c|c|}
\hline Treatment & $\begin{array}{l}\text { Proline } \\
\text { content } \\
\left(\mu g^{-1} \mathrm{FW}\right)\end{array}$ & $\begin{array}{l}\text { Leaf SOD } \\
\text { activity } \\
\text { (EU mg-1 } \\
\text { protein) }\end{array}$ & $\begin{array}{l}\text { Root SOD } \\
\text { activity } \\
\text { (EU mg-1 } \\
\text { protein) }\end{array}$ & $\begin{array}{l}\text { Leaf APX } \\
\text { activity } \\
\text { (EU mg-1 } \\
\text { protein) }\end{array}$ & $\begin{array}{l}\text { Root APX } \\
\text { activity } \\
\text { (EU mg-1 } \\
\text { protein) }\end{array}$ \\
\hline CK & $0.7 \pm 0.1^{\mathrm{a}}$ & $24.1 \pm 3.4^{\mathrm{a}}$ & $26.3 \pm 1.8^{a}$ & $62.9 \pm 8.4^{\mathrm{a}}$ & $84.3 \pm 3.8^{a}$ \\
\hline$C D$ & $2.6 \pm 0.2^{b}$ & $39.2 \pm 5.8^{b}$ & $48.4 \pm 3.8^{b}$ & $105.3 \pm 7.6^{b}$ & $143.7 \pm 12.1^{b}$ \\
\hline OF.D & $2.2 \pm 0.1^{b}$ & $60.6 \pm 6.1^{b}$ & $62.4 \pm 5.2^{b}$ & $156.5 \pm 8.6^{b}$ & $183.5 \pm 11.6^{b}$ \\
\hline BC.D & $1.9 \pm 0.2^{b}$ & $98.4 \pm 7.9^{c}$ & $97.4 \pm 7.1^{c}$ & $232.6 \pm 9.1^{c}$ & $287.2 \pm 11.8^{c}$ \\
\hline BF.D & $1.4 \pm 0.3^{b}$ & $106.2 \pm 7.3^{c}$ & $103.7 \pm 8.2^{c}$ & $269.4 \pm 17.1^{c}$ & $302.4 \pm 10.1^{c}$ \\
\hline \multicolumn{6}{|c|}{$\begin{array}{l}\text { Note: All values are the mean of three replicates } \pm \text { standard error of means. Different lowercase letters } \\
\text { indicate statistically significant difference between treatments }(p \leq 0.05) \text {. Details of treatments as given } \\
\text { in Table 1. BC Cd-resistant bacterial consortium after culture enrichment; BF Biofertilizer containing } \\
\text { indigenous Cd-resistant bacterial consortium; OF organic fertilizer as amendment control. FW fresh } \\
\text { weight; EU enzymatic unit; SOD superoxide dismutase; APX ascorbate peroxidase. }\end{array}$} \\
\hline
\end{tabular}

\section{Figures}
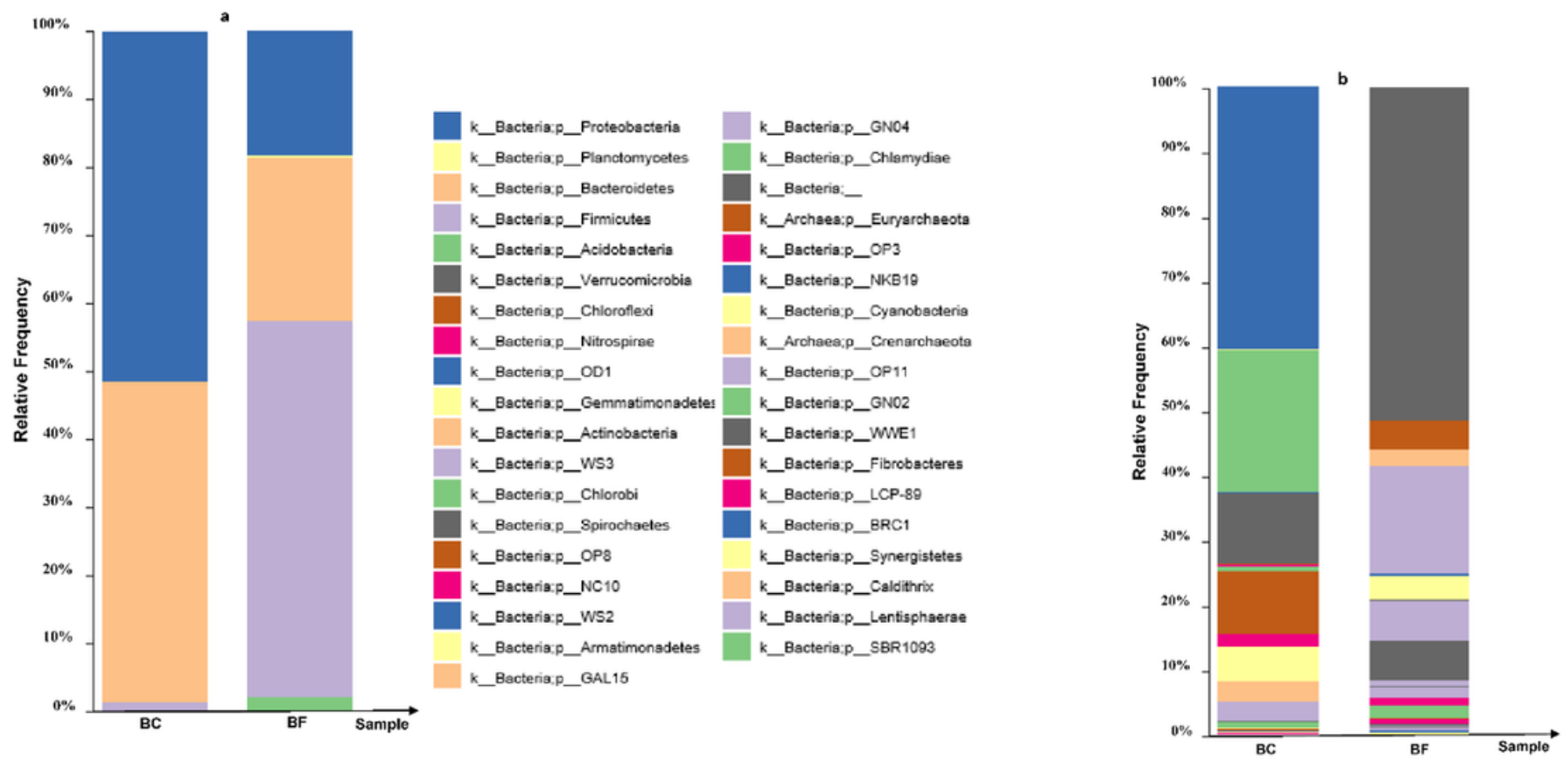

Figure 1 
Relative abundance levels of dominant bacterial phyla (a) and genera (b) in the enriched Cd-resistant bacterial consortium (BC) (cultivable $\mathrm{Cd}$ ) and the corresponding biofertilizer (BF) based on 16S rRNA gene Illumina MiSeq sequencing. The dominant phyla in the biofertilizer and the enriched bacterial consortium include Proteobacteria, Bacteroidetes, Firmicutes and Gemmatimonadetes.

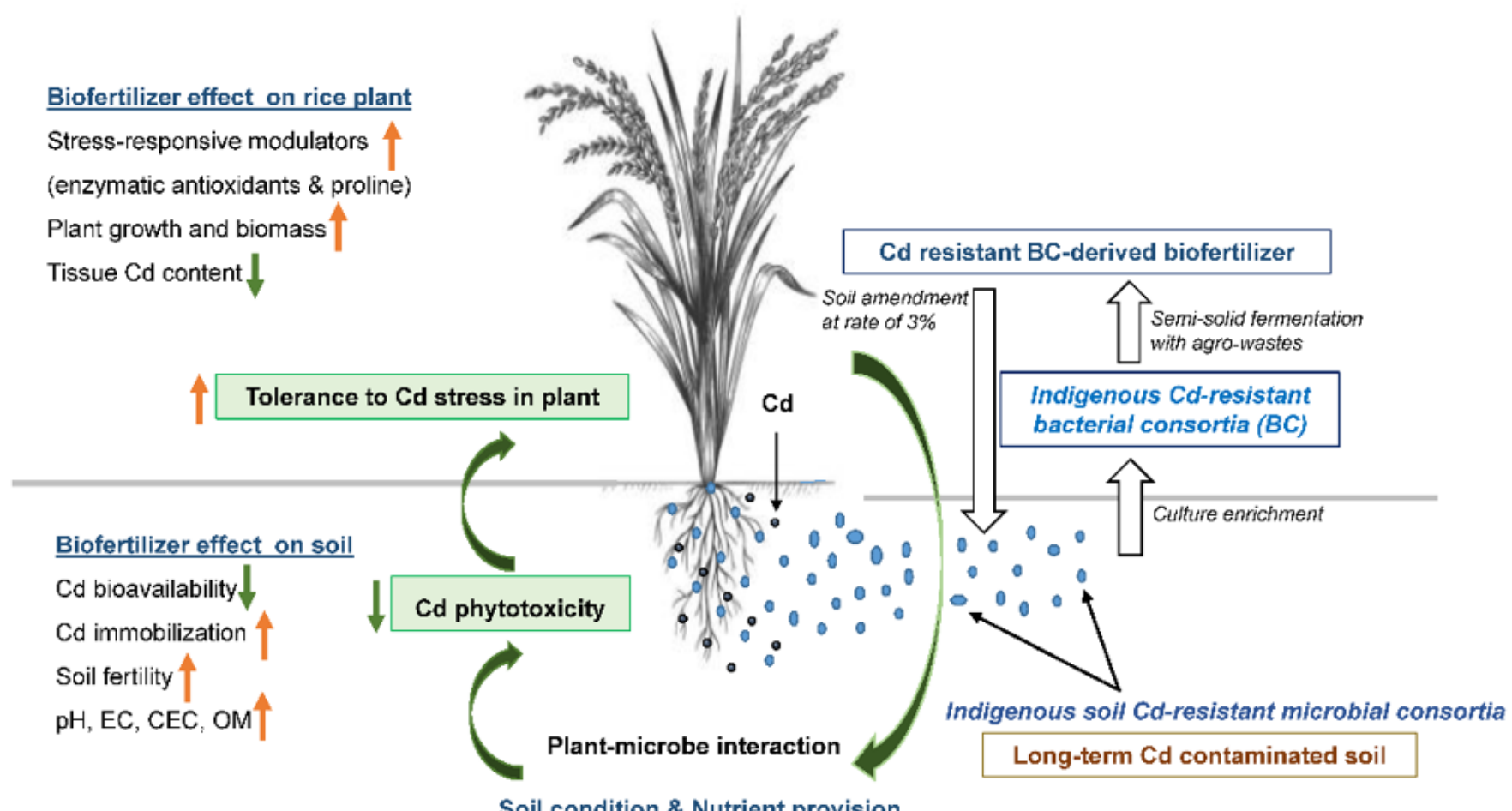

Soil condition \& Nutrient provision

Plant-growth promotion

\section{Figure 2}

Schematic diagram showing mitigating potential of indigenous Cd-resistant soil microbe-derived biofertilizer to $\mathrm{Cd}$ toxicity. Application of biofertilizer containing indigenous Cd-resistant soil microorganisms could alleviate Cd stress to PSL2 Thai rice cultivar grown in contaminated soil, due to improved soil biophysicochemical and nutrient availability leading to lower tissue $\mathrm{Cd}$ content and restored growth. Especially, soil pH increased after applying biofertilizer could limit soil Cd bioavailability and toxicity to rice roots. Beneficial phyla detected in the biofertilizer i.e., Bacteroidetes, Firmicutes and Proteobacteria, could help plant coping with Cd-induced oxidative stress by adjusting antioxidative defense, water relation and photosynthetic systems. 